\title{
Polikultur Tanaman Kelapa Sawit (Elaeis quineensis Jacq.) Dengan Tanaman Jelutung (Dyera polyphylla)
}

\author{
${ }^{1}$ Nasamsir dan ${ }^{2}$ Usman \\ ${ }^{1}$ Program Studi Agroteknologi Fakultas Pertanian Universitas Batanghari \\ ${ }^{2}$ Alumni Program Studi Agroteknologi, Fakultas Pertanian Universitas Batanghari \\ Jl. Slamet Riyadi, Broni Jambi, 36122. Telp. +62741 60103 \\ 1e-mail korenspondensi: nasamsirsamsir@yahoo.co.id
}

\begin{abstract}
Jelutung planting can be done between rows of oil palm plants, so as to produce optimal land growth and productivity. The research will be conducted in Betara and Bram Itam Kanan, Tanjung Jabung Barat, with the condition of peatland will be conducted from Mei to Juny 2019. This study aims to determine the value of land equivalent ratio (LER) in the intercropping of oil palm with jelutung plants. This research used survey method on farmers' land planted monoculture and intercropping with oil palm and jelutung plant. The location of this study was chosen intentionally because at these locations there is a cultivation of intercropping with oil palm and jelutung plants. The observed variables are; planting distance $(m)$, stem height $(m)$, stem circumference $(\mathrm{cm})$, leaf color, age of production (years), productivity of the oil palm and jelutung plants in intercropping (ton $h \mathrm{a}^{-1} \mathrm{thn^{-1 }}$ ), and land productivity. To answer the proposed hypothesis, the data obtained in the field is done statistical analysis with $Z$ test and descriptive method in the form of tabulation. The results showed that the production of oil palm and Jelutung monoculture system cropping were more than polyculture system cropping, but based on the calculation of the value of land equivalent ratio (LER), that value was 1.4 showed that polyculture plantations were $40 \%$ more profitable.
\end{abstract}

Keywords : intercropping, planting distance, land equivalent ratio

Abstrak. Penanaman jelutung dapat dilakukan di antara barisan tanaman kelapa sawit, sehingga menghasilkan pertumbuhan dan produktivitas lahan yang optimal. Penelitian dilakukan di Desa Betara dan Bram Itam Kanan Kabupaten Tanjung Jabung Barat, dengan kondisi lahan gambut. Penelitian dilaksanakan pada bulan Mei sampai Juni 2019. Penelitian ini bertujuan untuk menentukan nilai nisbah kesetaraan lahan (NKL) pada tanaman polikultur kelapa sawit dengan tanaman jelutung. Penelitian ini menggunakan metode survey pada lahan-lahan petani yang ditanami kelapa sawit dan jelutung monokultur dan polikultur tanaman kelapa sawit dengan tanaman jelutung. Lokasi penelitian dipilih secara sengaja karena pada lokasi-lokasi tersebut terdapat budidaya polikultur tanaman kelapa sawit dengan tanaman jelutung. Peubah yang diamati yaitu ; jarak tanam $(\mathrm{m})$, tinggi batang $(\mathrm{m})$, lingkar batang $(\mathrm{cm})$, warna daun, umur mulai produksi (th), produktivitas kelapa sawit dan jelutung secara polikultur (ton $h a^{-1} \operatorname{thn}^{-1}$ ), dan produktivitas lahan. Untuk menjawab hipotesis yang diajukan, data yang diperoleh di lapangan dilakukan analisis statistika dengan metode inferensi ( $\mathrm{Z}$ test) dan deskriptif dalam bentuk tabulasi. Hasil penelitian menunjukkan, produktivitas tanaman kelapa sawit dan jelutung pertanaman sistem monokultur lebih banyak dari pertanaman sistem polikultur, namun berdasarkan penghitungan nilai NKL sebesar 1,4 menunjukkan pertanaman polikultur lebih menguntungkan $40 \%$.

Kata kunci : polikultur, jarak tanam, nisbah kesetaraan lahan

\section{PENDAHULUAN}

Kelapa sawit merupakan salah satu komoditi sub sektor perkebunan yang memberikan andil besar dalam pemasukan devisa di luar sektor minyak dan gas bumi. Komoditi ini juga menyerap tenaga kerja yang cukup besar dan mampu memberikan kemakmuran bagi masyarakat yang mengusahakannya (Risza, 1994).

Setyamidjaja (2006) menyatakan bahwa tanaman kelapa sawit merupakan sumber penghasil minyak nabati yang digunakan secara luas dalam berbagai industri. Risza (1994) juga menjelaskan bahwa 
disamping digunakan sebagai bahan baku industri pangan, kelapa sawit dapat digunakan sebagai bahan baku industri non pangan.

Tanaman kelapa sawit termasuk tanaman multiguna. Tanaman tersebut mulai banyak mengantikan posisi pananaman komoditas perkebunan lain seperti tanaman karet. Tanaman kelapa sawit kini tersebar di berbagai daerah. Secara umum dapat diindikasikan bahwa pengembangan perkebunan kelapa sawit masih mempunyai prospek harga, ekspor dan pengembangan produk (Suwarto dkk., 2010)

Saat ini telah ada anjuran untuk membudidayakan kelapa sawit dengan mengkombinasikan dengan tanaman multi purpose tree species (MPTS) yaitu tanaman multi guna yang dapat menghasilkan, daun, kayu, buah dan juga mengantungkan bagi masyarakat. Tanaman kombinasi tersebut dapat berupa tanaman pangan, tanaman perkebunan atau tanaman MPTS seperti tanaman jelutung (Kemenhut, 2011).

Menurut Effendy (2010), jelutung rawa (Dyera polyphylla) adalah jenis pohon lokal yang sangat cocok untuk hutan tanaman yang memiliki hasil produksi tinggi dan ramah lingkungan pada lahan rawa gambut, karena mempunyai daya adaptasi yang baik dan telah teruji pada lahan rawa gambut. Jenis tumbuhan ini mempunyai pertumbuhan diameter 2,0-0,5 cm pertahun, tinggi 1,6-1,8 m pertahun, diameter batang bisa mencapai $260 \mathrm{~cm}$ dan tinggi mencapai $60 \mathrm{~m}$, bentuk batang silindris, tidak berbanir, kulit batang pohon dewasa berwarna kelabu kehitaman dan bila ditoreh kulitnya akan keluar getah berwarna putih. Selain itu jelutung juga dapat dibudidayakan pada lahan yang tidak terlalu luas dan mempunyai hasil ganda, getah (untuk permen karet, kosmetik, isolator dan kayu (untuk pensil slate, vinir dan moulding). Tumbuhan ini dapat dibudidayakan seperti tanaman karet, pada masa produktif disadap getahnya, pada akhir daur dapat dimanfaatkan kayunya.

Jelutung rawa (Dyera polyphylla) dapat disadap setelah diameter batang mencapai $>35 \mathrm{~cm}$. Penyadapan getah jelutung dilakukan dengan cara menyayat kulit batang pohon berbentuk huruf V. Hasil getah yang didapat sangat bervariasi (Effendy, 2010). Getah jelutung merupakan hasil metabolit sekunder atau cairan pohon yang berwarna putih, dengan nilai $\mathrm{pH}$ 4-5. Jika kondisi $\mathrm{pH}$ meningkat maka getah jelutung akan berubah warna menjadi coklat. Getah jelutung mengandung 43,4\% air, dan sisanya padatan total yang terdiri atas $23,63 \%$ bahan karet, $75,7 \%$ resin, $0,002 \%$ abu dan $0,68 \%$ debris atau kotoran. Kayu jelutung berwarna putih kekuningan,bertekstur halus, arah serat lurus dengan permukaan kayu yang licin mengkilap. Sifat kayu jelutung tersebut sangat cocok bila digunakan sebagai bahan baku kayu lapis, industri mebel, bubur kertas, pensil, dan patung (Tata $d k k ., 2015$ ).

Polikultur tanaman kelapa sawit dengan tanaman lain (interspesifik) masih belum dapat ditentukan apakah bersifat independent (tanaman tidak saling mempengaruhi), kompetitif (kenaikan hasil spesies tanaman yang satu mengakibatkan penurunan hasil lain, alelopati (sekresi atau eksresi atau zat toksik yang dikeluarkan oleh jenis tenaman tertentu dalam komoditas) atau stimulasi (produktivitas suatu tanaman akan ditingkatkan akibat keberadaan suatu spesies lain). Kompetisi tanaman polikultur ditentukan dari pengamatan lapangan berdasarkan pertumbuhan atau produksi tanaman (Edi $d k k$, (2003), Aminah, $d k k$, (2014)

Pengalihfungsian lahan hutan dan pemanfaatan kayu secara besar-besaran di kawasan hutan gambut Tanjung Jabung Barat mengakibatkan Jelutung menjadi sulit ditemukan dalam beberapa tahun ini, jelutung kembali banyak dibahas sebagai indigenous species untuk restorasi hutan dan spesies pohon komersial di lahan gambut (Sofiyuddin $d k k ., 2012$ ).

Apabila hasil hutan non kayu berupa getah jelutung dari areal rehabilitasi di Jambi dan Kalimantan dapat dimanfaatkan, potensi produksi getah jelutung 10 tahun ke depan mencapai lebih dari 1.500 ton per tahun. Dengan menggunakan asumsi potensi getah jelutung per pohon mencapai 0,36 gram (Bastoni dan Lukman, 2006).

Polikultur merupakan sistem budidaya tanaman yang dapat meningkatkan produktivitas lahan. Peningkatan ini dapat diukur dengan besaran yaitu NKL (Nisbah Kesetaraan Lahan) atau LER (land Equivalen Ratio). Hasil penelitian Dewi, dkk (2014), perlakuan tumpangsari tanaman padi gogo dengan tanaman jagung manis $(50 \mathrm{~cm} \times 70 \mathrm{~cm})$ cenderung memiliki hasil yang lebih tinggi dibandingkan dengan perlakuan tumpangsari yang lain. Hasil penelitian Nasamsir dan Irman (2018) menyimpulkan bahwa produktivitas tanaman pinang dan kelapa dalam pola tanam sistem tunggal lebih tinggi dari sistem tumpang 
sari. Namun berdasarkan perhitungan nilai NKL yang dihasilkan 1,46 (>1) menggambarkan bahwa sistem tumpang sari lebih menguntungkan dibandingkan sistem tunggal. Hasil penelitian lain yang dilakukan oleh Surtinah, dkk, (2016), nilai kesetaraan lahan pada system tumpang sai jagung manis dengan kangkung sutera adalah 1,83. Indeks persaingan antara jagung manis dan kangkung sutera adalah 1,73.

Tumpang sari kelapa sawit dengan jelutung merupakan sebuah kombinasi efektif untuk pemanfaatan lahan. Penanaman kelapa sawit dapat dilakukan di antara barisan tanaman jelutung yang sesuai dengan syarat tumbuhnya maka akan memberikan dampak yang yang baik sehingga menghasilkan pertumbuhan dan produksi yang optimal (Hulupi dan Martini, 2013).

Polikultur kelapa sawit dengan tanaman jelutung memiliki beberapa kelebihan yaitu mengoptimalkan pemanfaatan lahan yang ditujukan oleh NKL, menghasilkan produk yang beragam, memperoleh hasil tambahan, memperbaiki kesuburan tanah, dan mencegah erosi (Balai Perkajian Teknologi Pertanian, 2012).

\section{METODE PENELITIAN}

Penelitian ini dilaksanakan mulai tanggal 7 Mei sampai 7 Juni 2019 di Desa Bram Itam Raya Kecamatan Bram Itam dan Desa Sungai Landak Kecamatan Senyerang Kabupaten Tanjung Jabung Barat. Bahan yang digunakan dalam penelitian ini adalah pertanaman kelapa sawit yang berumur 8,5 tahun yang dipolikulturkan dengan jelutung berumur 8 tahun dan tanaman kelapa sawit monukultur berumur 8,5 tahun, sedangkan jelutung monokuktur berumur 9 tahun. Alat yang digunakan dalam penelitian ini meliputi GPS, meteran, timbangan, lembar kuisioner, bagan warna daun, lux meter, pisau deres, cuka getah 61, alat perekam dan kamera.

Penelitian ini mengunakan metode survey pada lahan-lahan yang ditanami dengan kelapa sawit monokultur, jelutung monokultur dan kelapa sawit polikultur dengan jelutung. Peubah yang diamati adalah jarak tanam $(\mathrm{m})$, tinggi tanaman $(\mathrm{m})$, lingkar batang $(\mathrm{cm})$, umur mulai produksi, produksi TBS kelapa sawit dan getah jelutung polikultur (ton $h a^{-1} \mathrm{thn}^{-1}$ ), produksi TBS kelapa sawit dan getah jelutung monokultur (ton $h a^{-1} \mathrm{thn}^{-1}$ ), warna daun, intensitas cahaya, suhu, kelembaban, dan produktivitas lahan. Pengambilan sampel menggunakan metode systemic sampling Analisis data mengunakan analisis statistika dengan metode deskripsif menggunakan tabulasi dan dilanjutkan uji inferensi menggunakan uji $\mathrm{Z}$ pada taraf $\alpha 5 \%$.

$$
z=\frac{x_{1}-x_{2}}{\sqrt{\frac{s_{1}^{2}}{n_{1}}+\frac{s_{2}^{2}}{n_{2}}}}
$$




\section{Hasil Penelitian}

\section{HASIL DAN PEMBAHASAN}

Hasil pengukuran jarak tanam, tinggi tanaman, lingkar batang, umur mulai produksi, produksi TBS kelapa sawit dan jelutung polikultur, produksi TBS kelapa sawit dan jelutung monokultur, warna daun, intensitas cahaya, suhu, kelembaban, produktivitas lahan secara rinci disajikan sebagai berikut :

Tabel 1. Hasil Pengamatan Peubah pada Sistem Pertanaman Monokultur dan Polikultur Kelapa Sawit dengan Jelutung.

\begin{tabular}{|c|c|c|c|c|c|c|}
\hline \multirow{2}{*}{ Peubah } & \multicolumn{6}{|c|}{ Pola Tanam } \\
\hline & MNK & PLK & MNK & PLK & Z- hit. & $P$ \\
\hline & K. sawit & & Jelutung & & & \\
\hline Jarak tanam (m) & $8 \times 7$ & & $4 \times 3$ & $4 \times 3,5$ & & \\
\hline Tinggi tanaman (m) & 7 & 8 & 12,7 & 12,2 & 10,155 & 0,000 \\
\hline Lingkar Batang $(\mathrm{cm})$ & 235 & 233 & 30,5 & 28,7 & 4,779 & 0,000 \\
\hline Umur mulai prod. (th) & 4 & 4 & 8 & 8 & & \\
\hline $\begin{array}{l}\text { Estimasi produktivitas } \\
\left(\text { ton ha }{ }^{-1} \text { thn }^{-1} \text { ) }\right.\end{array}$ & 38,68 & 35,00 & 16,83 & 8,40 & 3,533 & 0,000 \\
\hline Warna daun & lebih hijau & hijau & lebih hijau & hijau & & \\
\hline $\begin{array}{l}\text { Intensitas cahaya } \\
\left(\operatorname{lux} x^{-10}\right)\end{array}$ & 552 & & 491 & 546 & & \\
\hline Suhu $\left({ }^{0} \mathrm{C}\right)$ & 23 & & 22 & 23 & & \\
\hline Kelembapan (\%) & 80 & & 90 & 85 & & \\
\hline
\end{tabular}

Keterangan : MNK : monokultur PLK : polikultur. Berbeda nyata $P<0.005$

\section{Produktivitas Lahan}

Berdasarkan hasil estimasi produksi, dapat diketahui produktivitas lahan pada penanaman polikultur yang dihitung menggunakan rumus Nisbah Kesetaraan Lahan ( NKL ) .

$$
\begin{aligned}
\mathrm{NKL}= & \frac{\mathbf{3 5 . 0 0 1 , 5}}{38.689,7}+\frac{8.405,7}{16.839,8} \\
& =0,9+0,5 \\
& =1,4
\end{aligned}
$$

Berdasarkan hasil penghitungan estimasi, rata-rata produktivitas lahan (NKL) tanaman polikultur kelapa sawit dengan jelutung adalah 1,4 ( NKL $>1)$.

\section{Pembahasan}

Jarak tanam 7 × 8 meter pada pertanaman kelapa sawit polikultur dengan jelutung sangat berpengaruh pada pertumbuhan dan produksi karena terjadi persaingan untuk mendapatkan unsur hara, air, dan cahaya matahari. Hal ini terjadi karena pada sistem polikultur populasi tanaman lebih banyak (melebihi populasi optimum) sehingga akan terjadi persaingan dalam penyerapan unsur hara dan air dari dalam tanah (Herlina, 2011). Berbeda dengan tanaman yang ditanam pada sistem monokultur, tanaman tidak mengalami persaingan untuk mendapatkan air, unsur hara, dan cahaya matahari.

Lingkar batang tanaman jelutung pada pertanaman polikultur hanya rata- rata $28.7 \mathrm{~cm}$, berbeda dengan lingkar batang pada pertanaman monokultur yang mencapai $30.5 \mathrm{~cm}$. Lingkar batang tanaman kelapa sawit pada pertanaman polikultur rata- rata $233 \mathrm{~cm}$, lebih kecil dari lingkar batang pertanaman kelapa sawit monokultur yaitu $235 \mathrm{~cm}$. Kondisi ini juga disebabkan adanya persaingan untuk mendapatkan unsur hara, air dan cahaya matahari sehingga berpengaruh pada lingkar batang setiap tanaman.

Tinggi tanaman kelapa sawit pertanaman monokultur adalah $7 \mathrm{~m}$ dan pertanaman polikultur $8 \mathrm{~m}$, sedangkan tinggi tanaman jelutung pertanaman monokultur mencapai $12,7 \mathrm{~m}$ dan pertanaman polikultur $12,2 \mathrm{~m}$. Tinggi tanaman kelapa sawit sistem monokultur lebih rendah dibandingkan dengan yang polikultur. Sejalan dengan pendapat Herlina (2011), pada sistem polikultur proses fotosentesis yang tidak maksimal mengakibatkan produktivitas kedua tanaman menjadi rendah. Selain itu akibat dari tumpang tindih kedua tajuk tanaman mengakibatkan terjadi pertumbuhan yang meninggi. 
Umur mulai produksi pertanaman monokultur dan polikultur kelapa sawit sama, yaitu umur 4 tahun dan umur mulai produksi tanaman Jelutung pertanaman monokultur dan polikultur juga sama yaitu umur 8 tahun.

Warna daun kelapa sawit dan jelutung sistem pertanaman monokultur lebih hijau dibanding pertanaman polikultur, karena tanaman polikultur mengalami kekurangan cahaya dan unsur hara. Berbeda dengan sistem pertanaman monokultur, tidak terjadi persaingan tanaman untuk mendapatkan unsur hara, air, dan cahaya. Daun tanaman yang memperoleh cahaya yang cukup secara mikromorfologi mengandung klorofil yang lebih banyak dibanding daun tanaman yang mengalami kekurangan cahaya.

Estimasi produksi kelapa sawit pertanaman monokultur yaitu 38,68 ton ha ${ }^{-1} \mathrm{thn}^{-1}$ lebih banyak dibandingkan dengan kelapa sawit pertanaman polikultur yaitu 35,00 ton ha $\mathrm{ha}^{-1} \mathrm{thn}^{-1}$, sedangkan estimasi produksi tanaman jelutung pertanaman monokultur yaitu 16,83 ton ha ${ }^{-1} \mathrm{thn}^{-1}$ dan pertanaman polikultur adalah 8,40 ton ha ${ }^{-1} \mathrm{thn}^{-1}$. Estimasi ini didasakan pada asumsi bahwa semua tanaman dalam 1 hektar memiliki produksi dan frekuensi panen yang sama dengan tanaman sampel.

Intensitas cahaya yang cukup akan membantu tanaman dalam proses fotosentsis sehingga akan berdampak pada pertumbuhan dan produktivitasnya, apa lagi tanaman kelapa sawit yang membutuhkan cahaya matahari penuh. Pada Tabel 1 terlihat bahwa intensitas cahaya pertanaman kelapa sawit monokultur lebih tinggi dari pada pertanaman polikultur. Tajuk tanaman kelapa sawit dan tajuk tanaman jelutung saling tindih, mengakibatkan persaingan mendapatkan sinar matahari yang dibutuhkan untuk proses fotosentesis. Disamping itu tanaman kelapa sawit membutuhkan cahaya penuh, pada kondisi kekurangan cahaya pertumbuhan tanaman Kelapa sawit akan lebih tinggi ( Herlina, 2011 ).

Selain air dan unsur hara, energi cahaya matahari merupakan salah satu faktor penting untuk mendukung pertumbuhan dan perkembangan tanaman. Cahaya matahari dibutuhkan oleh tanaman sebagai sumber energi pada proses fotosintesis. Fotosintat sebagai hasil dari proses fotosintesis dimobilisasi dan digunakan untuk mendukung pertumbuhan dan perkembangan tanaman pada fase vegetatif dan generatif. Menurut Sasmita dkk (2006), naungan akan menurunkan aktivitas fotosintesis yang akan mengakibatkan penurunan fotosintat. Kondisi ini yang kemudian menyebabkan ketersediaan energi cahaya matahari menjadi dasar pertimbangan untuk pemilihan jenis tanaman sela tumpangsari dan sampai berapa lama dapat terus diusahakan.

Suhu pertanaman pada sistem monokultur lebih tinggi dibandingkan dengan sistem polikultur karena sistem pertanaman monokultur mendapatkan cahaya penuh, berbeda dengan tanaman sistem polikultur yang mengalami persaingan mendapatkan cahaya. Di daerah yang musim kemaraunya panjang pertumbuhan vegetatif kelapa sawit dapat terhambat, suhu berpengaruh pada produksi melalui pengaruh terhadap laju reaksi biokimia dan metabolisme dalam tubuh tanaman. Sampai batas tertentu, suhu yang lebih tinggi menyebabkan meningkatkan produksi buah. Suhu $20{ }^{\circ} \mathrm{C}$ disebut sebagai batas minimum bagi pertumbuhan vegetatif dan suhu rata-rata tahunan $22-23{ }^{\circ} \mathrm{C}$ diperlukan untuk berlangsungnya produksi buah ( Mangoensoekarjo dan Semangun, 2005 ).

Kelembaban udara pada pertanaman kelapa sawit monokultur lebih rendah dibandingkan dengan pertanaman kelapa sawit polikultur, tetapi berbeda dengan pertanaman jelutung, pertanaman jelutung monokultur lebih tinggi kelembabannya dibandingkan dengan pertanaman polikultur. Kelembaban udara optimum terhadap kelapa sawit sekitar 80 - $90 \%$ ( Arsyad, 2012 ).

Sebaran sinar matahari sangat penting, hal ini bertujuan menghindari persaingan antar tanaman yang dipolikulturkan dalam mendapatkan cahaya. Perlu juga diperhatikan tinggi tanaman dan luas antar tajuk tanaman, karena berpengaruh terhadap penerimaan cahaya matahari dan fotosentesis ( Herlina, 2011 ).

Dari perhitungan nilai kesetaraan lahan, diperoleh nilai $\mathrm{NKL}=1,4$. Hal ini menggambarkan sistem polikultur lebih menguntungkan $40 \%$ dibandingkan sistem monokultur. Nisbah kesetaraan lahan merupakan salah satu cara menghitung produktivitas lahan yang ditanami 2 atau lebih tanaman yang dipolikulturkan. Sistem polikultur lebih menguntungkan jika NKL > 1, apabila nilai NKL=1 menunjukan tidak ada perbedaan produktivitas lahan antara sistem pertanaman monokultur dan polikultur. 


\section{KESIMPULAN}

Dari hasil penelitian dapat ditarik kesimpulan bahwa produktivitas tanaman kelapa sawit dan jelutung pertanaman monokultur lebih banyak dari pertanaman sistem polikultur. Namun berdasarkan penghitungan nilai nisbah kesetaraan lahan (NKL) menujukan nilai 1,4, menggambarkan bahwa pertanaman sistem polikultur lebih menguntungkan dibandingkan monokultur

\section{DAFTAR PUSTAKA}

Arsyad, S. 2012. Konservasi Tanah dan Air. IPB Press. Bogor. Hal. 327-328

Aminah, I.S, Rosmiah dan M. Haris Yahya. 2014. Efisiensi Pemanfaatan Lahan Pada Tumpangsari Jagung (Zea mays L.) dan Kedelai (Glycine Max L. Merrill) di Lahan Pasang Surut. Jurnal Lahan Suboptimal. Vol. 3, No.1: 62-70, April 2014

Balai Pengkajian Teknologi Pertanian. 2012. Jurnal Litbang Pert. Vol. 4 Desember 2012. Jawa Timur.

Bastoni dan A.H. Lukman. 2006. Prospek Pengembangan Hutan Tanaman Jelutung Pada Lahan Sumatra.

Seminar Hasil-Hasil Penelitian "Optimalisasi Peran IPTEK dalam Mendukung Peningkatan Produktivitas Hutan dan Lahan”.Prosiding Seminar Hasil Penelitian. Jambi, 22 Desember 2005.

Dewi, S.S., R. Soelistyono, dan A. Suryanto. 2014. Kajian Pola tanam Tumpang Sari Padi Gogo dengan Jagung Manis. Jurnal Produksi Tanaman.Vol. 2 (2). Maret 2014. Hal. 137-144

Edi, W dan Zainal, M. 2003.Tanaman Sela di Antara Pertanaman Kelapa Sawit. (http://peternakan.litbang.pertanian.go.id/fullteks/lokakarya/probklu0318.pdf?secure=1). Diakses $17 / 02 / 2015$

Effendy, M. 2010. Prospek Budidaya Tanaman Jelutung Rawa (Dyera lowii). Galam, Vol 4(3): 233-242.

Handayani, A. 2010. Pengaruh Model Tumpang Sari Terhadap Pertumbuhan dan Hasil Tanaman Gandum dan Tembakau. Widyariset. Vol. 14 (3). Desember 2011.Hal 479-488.

Herlina. 2011. Kajian Variasi Jarak dan Waktu Tanam Jagung Manis Dalam Sistem Tumpangsari Jagung Manis (Zea mays saccarata Sturt) dan Kacang Tanah (Arachis hypogeal L).Pogram Pascasarjana Universitas Andalas, Padang.

Hulupi, R dan E. Martini. 2013. Pedoman Budi Daya dan Pemeliharaan Tanaman Kopi di Kebun Campur. Pusat Penelitian Kopi dan Kakao Indonesia. Bogor.

https://jambi.bps.go.id/dynamictable/2018/04/18/396/luas-tanaman-kelapa-sawit-menurut-kabupaten-kota2007-2016.html

http://abrur14.blogspot.co.id/2014/08/jelutung-dyera-pollyphylla.html

Kementerian Kehutanan.2011..Blogspot.com/2011/jenis tanaman agroforestry. html.Bogor.

Lubis R.S dan Agus,W. 2011. Buku Pintar Kelapa Sawit ( Elaeis guineensis Jacq). Agro Media Pustaka. Jakarta. 296 hal.

Mangoensoekarjo, S. dan H. Semangun. 2005. Manajemen Agribisnis Kelapa Sawit. Gajah Mada Univ. Press. Jogjakarta. 605 hal.

Nasamsir dan Irman. 2019. Pertumbuhan dan Produksi Tanaman Pinang dan Kelapa Sistem Tumpang Sari. Jurnal Media Pertanian. Vol. 3 (1). Hal. 1-9.

Risza.S, 1994. Kelapa Sawit. Upaya Peningkatan Produktivitas. Penerbit Kanasius. Yogyakarta.

Salisbury, F. B., dan Ross, C. W. 1995. Fisiologi Tumbuhan. Bandung: ITB Bandung

Sasmita, P., Purwoko, B. S., dan Sujiprihati, S. 2006. Evaluasi Pertumbuhan dan Produksi Padi Gogo

Haploid Ganda Toleran Naungan dalam Sistem Tumpang sari. Buletin Agronomi, 34(2), 79-86.

Setyamidjaja, D. 2006. Budidaya Kelapa Sawit.Kanisius.Kanisius. Yogyakarta.

Surtinah, Neng, S, dan S.U. Lestari 2016. Optimasi Lahan Dengan Sistem Tumpang Sari Jagung Manis dan Kangkung Sutra di Pekanbaru. Jurnal Ilmiah Pertanian. Vol. 12 (2). Hal. 61-71.

Suwarto dan Octavianty, Y. 2010. Budidaya Tanaman Perkebunan Unggul, Penebar Swadaya. Jakarta.

Sofiyuddin, M., Janudianto, dan Perdana A. 2012. Potensi Pengembangan dan Pemasaran Jelutung di Tanjung Jabung Barat.Brief, Vol 1(23): 1-2.

Tata, H.L., Bastoni, M. Sofiyuddin, Elok, M., Aulia, P. dan Janudianto. 2015.mJelutung Rawa Teknik Budidaya dan Prospek Ekonominya. Bogor: World Agroforestry Centre (ICRAF). 
Nasamsir dan Usman. Polikultur Tanaman Kelapa Sawit (Elaeis Quineensis Jacq.) Dengan Tanaman Jelutung (Dyera Polyphylla)

Tasri, E.S. 2007. Metodologi Penelitian Ekonomi dan Bisnis. Universitas Bung Hatta, Padang.

Yuwariah,Y.D. Ruswandi, A.W. Irwan. 2017. Pengaruh Pola Tanam Tumpangsari Jagung Dan Kedelai Terhadap Pertumbuhan Dan Hasil Jagung Hibrida Dan Evaluasi Tumpangsari Di Arjasari Kabupaten Bandung. Jurnal Kultivasi Vol. 16 (3) Desember 2017 